\title{
Influence of microenvironments on microcirculation patterns and tumor invasion-related protein expression in melanoma
}

\author{
LUXIA CHEN ${ }^{1}$, BAOCUN SUN ${ }^{2,3}$, SHIWU ZHANG $^{2}$, XIULAN ZHAO $^{3}$, YANJIN HE ${ }^{1}$, \\ SHAOZHEN ZHAO ${ }^{1}$, TINGTING LIN ${ }^{1}$ and XIAORONG LI ${ }^{1}$ \\ ${ }^{1}$ Eye Center of TianJin Medical University, TianJin 300070; ${ }^{2}$ Department of Pathology, TianJin Cancer Hospital, \\ TianJin; ${ }^{3}$ Department of Pathology, TianJin Medical University, TianJin 300070, P.R. China
}

Received December 11, 2008; Accepted January 16, 2009

DOI: 10.3892/or_00000304

\begin{abstract}
This study aimed to investigate the influence of different microenvironments on melanoma microcirculation patterns, invasiveness and metastatic behavior. Sixty C57BL/6J mice were randomly divided into two groups with 30 mice per group. Melanoma B16 cells were injected into the subretinal space and groin area of mice synchronously. The number of each type of microcirculation pattern was counted. Invasion and metastasis were observed. Epithelial cell kinase (EphA2), matrix metalloproteinase (MMP)-2 and -9 expression and their mRNA levels were detected by immunohistochemical staining and real-time PCR and compared between the two groups. Five invasions and six lung metastases were found in the subretinal group while no invasion and metastasis were found in the groin group. The number of vasculogenic mimicry (VM) was significantly higher in the subretinal group $(\mathrm{P}=0.000)$. However, no significant difference in the numbers of mosaic and endothelium-dependent vessels was observed between the two groups $(\mathrm{P}=0.076$ and 0.146 , respectively). EphA2, MMP-2 and MMP-9 expression was significantly higher in the subretinal group. The mRNA levels of EphA2, MMP-2 and MMP-9 were slightly higher in the subretinal tumors $(\mathrm{P}=0.002,0.001$ and 0.001 , respectively). In conclusion, this experimental paradigm can be a powerful one in which to investigate tumor-microenvironment interactions in melanoma. Tumor cells in the intraocular microenvironment had increased EphA2 expression which induced the formation of VM channels. Moreover, expression of MMP-2 and -9 in tumor tissue was increased to enhance the invasiveness and metastatic behavior.
\end{abstract}

Correspondence to: Dr Xiaorong Li, Eye Center of TianJin Medical University, TianJin 300070, P.R. China

E-mail: lq1012@yahoo.com.cn

Key words: melanoma, microenvironment, vasculogenic mimicry, matrix metalloproteinase, epithelial cell kinase

\section{Introduction}

The concept of 'vasculogenic mimicry' (VM) was introduced to describe the unique ability of highly invasive tumor cells to form capillary-like structures (CLS) and a matrix-rich patterned network. Melanoma cells have the ability to mimic endothelial cells and form VM channels $(1,2)$. VM channels connect with endothelium-dependent vessels to create a network that provides for tumor growth, invasion and metastasis (3). Although the molecular mechanism of VM channel formation is still unclear (4), it is possible that a change in microenvironment induces VM channel formation directly to enhance the behavior of tumor metastasis (5). A poor intraocular microenvironment can activate some invasionand metastasis-associated tumor genes, enabling cells to become more invasive for survival $(6,7)$. Epithelial cell kinase (EphA2) plays critical and diverse roles in regulating cell adhesion, migration and proliferation. It was revealed that increased expression of EphA2 in aggressive melanoma cells plays an important role in mediating VM. Matrix metalloproteinases (MMPs) can degrade many components of the extracellular matrix (ECM) and basement membrane. They can contribute to cancer growth, invasion and angiogenesis (8). Upon immunohistochemical staining, MMP-2 and -9 were found to co-localize with VM, and they are thought to play an important role in VM formation $(5,9,10)$. In this study, we hypothesized that the local tumor microenvironment affects the formation of VM channels, the number of tumor metastases and expression of EphA2, MMP-2 and MMP-9 in xenografted and orthotopic melanoma.

\section{Materials and methods}

Animals and cell line. Sixty C57BL/6J mice, 30 males and 30 females, were used in this study. They included 6- to 8-weekold black mice weighing 20-25 g, purchased from the Experimental Animal Institute of the Chinese Academy of Medical Science (Beijing). All 60 mice were randomly divided into two groups with 30 mice per group.

A suspension of B16 cells ( $1 \times 10^{5}$ cells/mouse) was injected into the left groin area and the right subretinal space. The skin of the left groin area in each mouse was sterilized with 
$75 \%$ alcohol, and a $0.1-\mathrm{ml}$ cell suspension $\left(1 \times 10^{6}\right.$ cells $\left./ \mathrm{ml}\right)$ was injected into this area. The right eyes of the mice received microscopically guided subretinal injections of $0.004 \mathrm{ml}$ of a cell suspension $\left(4 \times 10^{8}\right.$ cells $\left./ \mathrm{ml}\right)$. By the 14 th day, the engrafted tumors were palpated, and the mice were sacrificed. Some fresh tumor masses were collected for realtime PCR and some were fixed and embedded followed by immunohistochemical staining.

Immunohistochemical staining. The tumors were removed, fixed with formalin and embedded in paraffin. Then the tissue was cut into 4- $\mu \mathrm{m}$ sections to be placed on slides, dried overnight at $65^{\circ} \mathrm{C}$ and deparaffinized in xylene. The sections were rehydrated through graded alcohols into water. Endogenous peroxidase was blocked with $3 \%$ hydrogen peroxide in $50 \%$ methanol for $10 \mathrm{~min}$ at room temperature. After rehydrating, the sections were washed with PBS and pretreated with citrate buffer $(0.01 \mathrm{M}$ citric acid, $\mathrm{pH}$ 6.0) for $20 \mathrm{~min}$ at $100^{\circ} \mathrm{C}$ in a microwave oven. After rinsing with PBS, slides were incubated overnight at $4^{\circ} \mathrm{C}$ with primary polyclonal antibodies, including the antibodies against EphA2 (Upstate, NY, USA, dilution 1:100), MMP-2 (BA0596) and MMP-9 (BAO573) (both from Boster Biological Technology Ltd., Wuhan, P.R. China, dilution 1:100). The sections were then washed with PBS and incubated with the secondary antibody for $30 \mathrm{~min}$ at $37^{\circ} \mathrm{C}$. The sections were incubated with HRP-conjugated antibody for $30 \mathrm{~min}$ at $37^{\circ} \mathrm{C}$ after the PBS washes. Visualization was performed using a DAB Kit (DC 10, Boster Biological Technology Ltd.) according to the manufacturer's instructions. The sections were then incubated in $95 \%$ alcohol with agitation for $30 \mathrm{~min}$ to remove formalin granules. After washing in running water, the sections were incubated in potassium permanganate for $3 \mathrm{~h}$ and bleached with $2 \%$ oxalic acid for $5 \mathrm{~min}$. The nuclei were counterstained with hematoxylin, followed by dehydration and cover-slip mounting. Appropriate positive and negative controls were included.

Quantitation of VM channels, mosaic vessels (MV) and microvessel density and immunohistochemistry. VM channels, $\mathrm{MV}$ and endothelium-dependent vessels in the H\&E-stained sections were counted using x400 magnification. Five fields were chosen randomly, and the average blood supply pattern was defined as the number of microvessels or channels in one section. The endothelium-dependent vessels, mosaic vessels and VM channels were counted in every visual field, and the channels lined with melanoma cells, containing red cells, without necrosis or inflammatory cells, were considered as VM. The mean value of the necrotic and each type of microvessel in five fields was the final outcome. Expression of MMP-2, MMP-9 and EphA2 in tumor cells was determined by counting the percentage of positive cells in 100 tumor cells with a cell counter. The counting was carried out as follows. Five microscopic fields in one section were observed under x400 magnification, and positive cells were counted in 100 tumor cells per field. The average percentage of five fields was the final score.

Real-time PCR. Total RNA was extracted with Trizol reagent according to the manufacturer's instructions. Complementary
DNA (cDNA) was synthesized and amplified from total RNA using the Access Real-time PCR system (Takara Biotechnology Co., Ltd., Japan). Real-time PCR primers for MMP-2 and -9 were designed by Primer 5.0 according to the sequences in Gene Bank. The primer sequences used for MMP-2 (gene ID 17390) detection were 5'-GATAACCTG GATGCCGTCGTG-3' (sense) and 5'-CTTCACGCTCTTG AGACTTTGGTTC-3' (antisense) $(\mathrm{TM}=53.1)$. The primer sequences used for MMP-9 (gene ID 17395) detection were 5'-GCCCTGGAACTCACACGACA-3' (sense) and 5'-TTGG AAACTCACACGCCAGAAG-3' (antisense) (TM=53.1). The forward primer for EphA2 (gene ID 067552) was 5'-CC GTGTGGAAGTACGAAGTCA-3' and the reverse primer was 5'-GGTACGTGGTATCCGGAGCAAG-3' (TM=64). The forward $ß$-actin primer was 5'-CATCCGTAAAGACC TCTATGCCAAC-3', and the reverse primer was 5'-ATGGA GCCACCGATCCACA-3'. The resultant cDNA products of MMP-2, MMP-9, EphA2 and B-actin were 109, 86, 119 and 174 base pairs. Real-time PCR was performed in the Gene AMP PCR System 5700 Sequence Detector (ABI, USA). Every sample was analyzed in triplicate. The CT value (the cycle number at which the fluorescence crosses the threshold) was measured and $2^{-\Delta \mathrm{CT}}\left({ }^{\Delta} \mathrm{CT}=\mathrm{CT}_{\text {target genes }}-\mathrm{CT}_{\mathrm{B} \text {-actin }}\right)$ was defined as the quantity of the amplified fragment.

Statistical analyses. All analyses were performed using SPSS 11.5 (SPSS Inc., USA). A P-value $<0.05$ was defined as statistically significant. A t-test for the two groups was used to analyze the difference in protein expression and the number of VM channels, endothelium-dependent vessels and necrotic cells.

\section{Results}

Growth and metastasis in the different melanoma models. Two weeks after injection, the subretinal masses had enlarged considerably, and a more or less pronounced proptosis was visible in all animals. All mice in the model were sacrificed, and soft black engrafted tumor masses were observed in the right eye (Fig. 1A). In comparison, 14 days after melanoma injection, the subcutaneous engrafted tumors were observed in the left groin area, and rich blood vessels were noted on the surface of the tumors (Fig. 1B). Five tumors in the subretinal group extended into the orbit, and six models of micrometastases of lungs were found in the subretinal group by gross pathological examination of all internal organs (Fig. 1C) while no adjacent tissue invasion and lung metastasis were found in the groin group, which indicated that melanoma cells in the subretinal group were more invasive than in the groin group. Results from the H\&E-stained sections indicated numerous black and brown melanin granules on the tumor micrometastases of the lungs in the subretinal group (Fig. 1D) while no metastasis was found in the groin group. Comparison of tumor metastasis by counting the lung metastases confirmed that mice in the subretinal group carried a significantly greater metastatic burden than mice in the groin group $(\mathrm{t}=2.963, \mathrm{P}=0.009)$.

VM channels, mosaic vessels and endothelium-dependent vessels in different microenvironments. There were three 

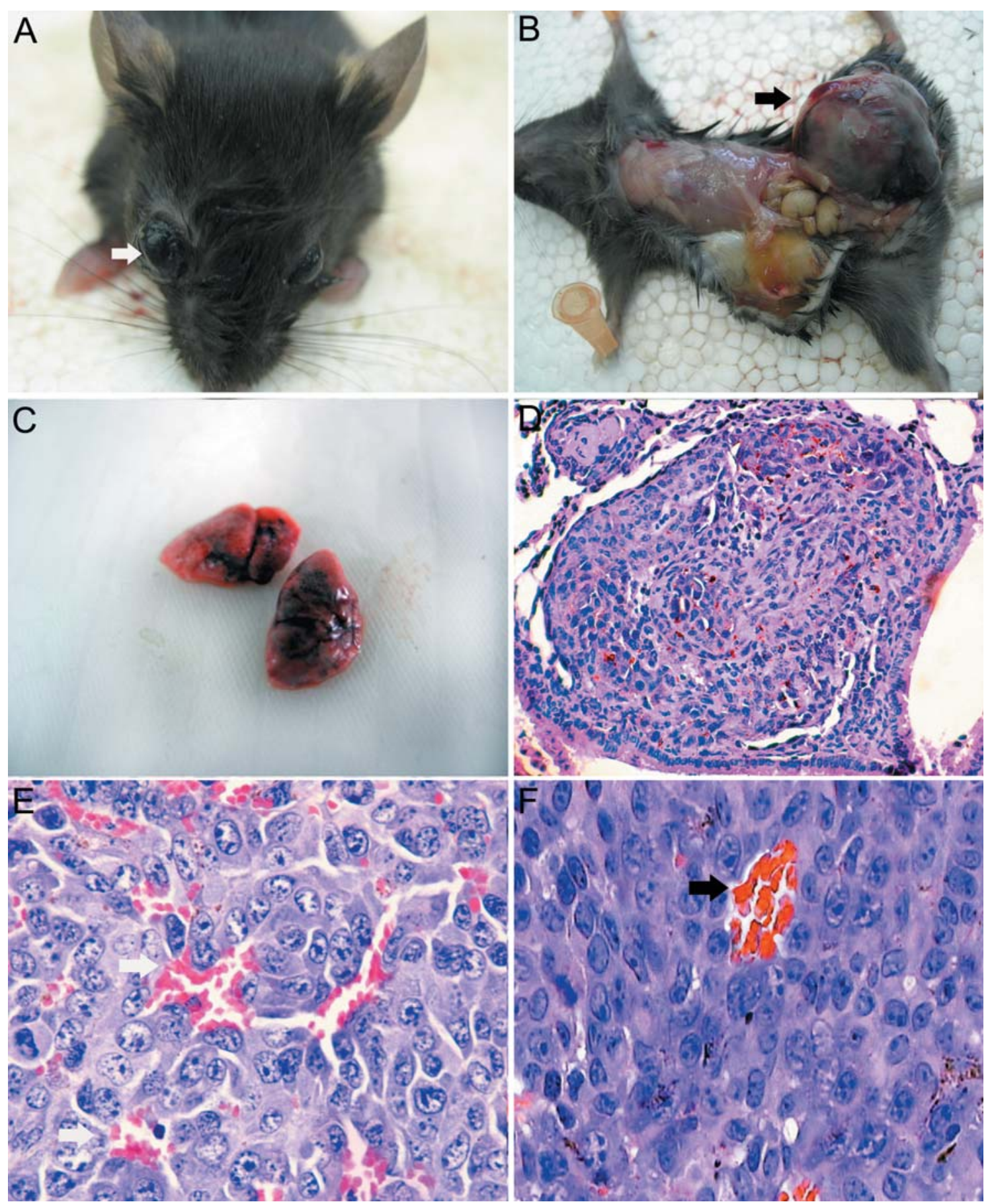

Figure 1. (A) A C57BL1/6J mouse bearing B16 melanoma with pronounced proptosis of the right eye (white arrow, tumor). (B) A soft black tumor mass in the groin area and vessels were viewed on the surface of the tumor (black arrow, tumor). (C) Tumor micrometastases of the lung (black, spot-like) which invaded the lung tissues in the subretinal group. (D) Numerous black and brown melanin granules on the tumor micrometastases of the lung (H\&E, $\mathrm{x} 200$ ). (E) A large number of VM channels (white arrow) with red blood cells in a tumor from the subretinal group (H\&E, x400). (F) Compared with the subretinal group, there were less VM channels (black arrow) in tumors of the groin group.

microcirculation patterns in the engrafted melanoma in different microenvironments from the subretinal space and the groin area. VM channels and mosaic vessels contained red cells, and no necrosis or inflammatory cells were observed around them, indicating that they were functional vessels for melanoma blood supply. An unpaired t-test was performed to analyze the difference in the number of VM channels and endothelium-dependent vessels between subretinal space tumors and those in the groin area. The subretinal tumors had more VM channels than the groin tumors (Fig. 1E and F). These findings demonstrated that different microenvironments influence VM formation. We observed an abundance of mosaic vessels and endothelium-dependent vessels in the tumors of both the subretinal and groin groups. No significant difference in tumor mosaic vessels and endotheliumdependent vessels was observed between the two groups. The results of H\&E staining for VM channels and endotheliumdependent vessels are shown in Fig. 2. 


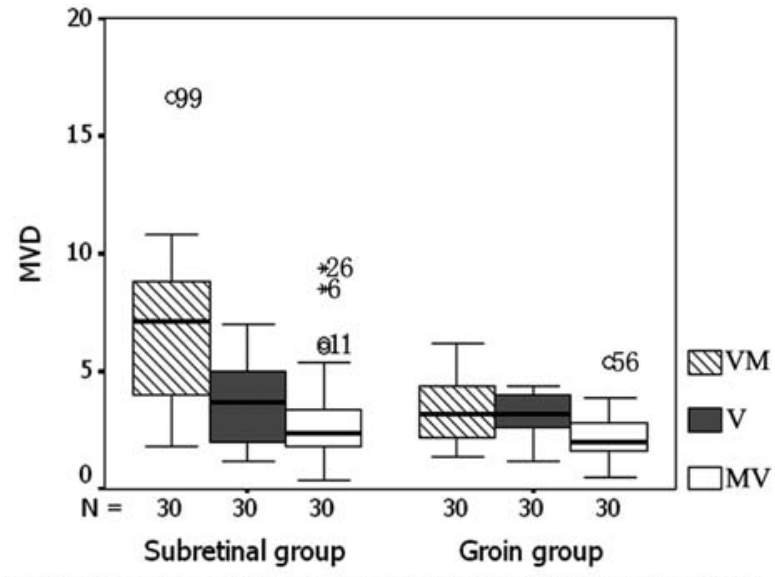

Figure 2. There were more VM channels in melanoma tumors in the subretinal group than in the groin group $(\mathrm{P}=0.000)$. However, the difference in the number of endothelium-dependent vessels and mosaic vessels between the two groups had no statistical significance ( $\mathrm{P}=0.146,0.076$, respectively). The horizontal line inside the box represents the median. The outliers are cases with values between 1.5 and 3 box-lengths from the 75th percentile or the 25 th percentile. The extreme values are cases with values $>3$ box-lengths from the 75 th or 25 th percentile.

VM:VM channels V:endothelium-dependent vessels MV:Mosaic vessels
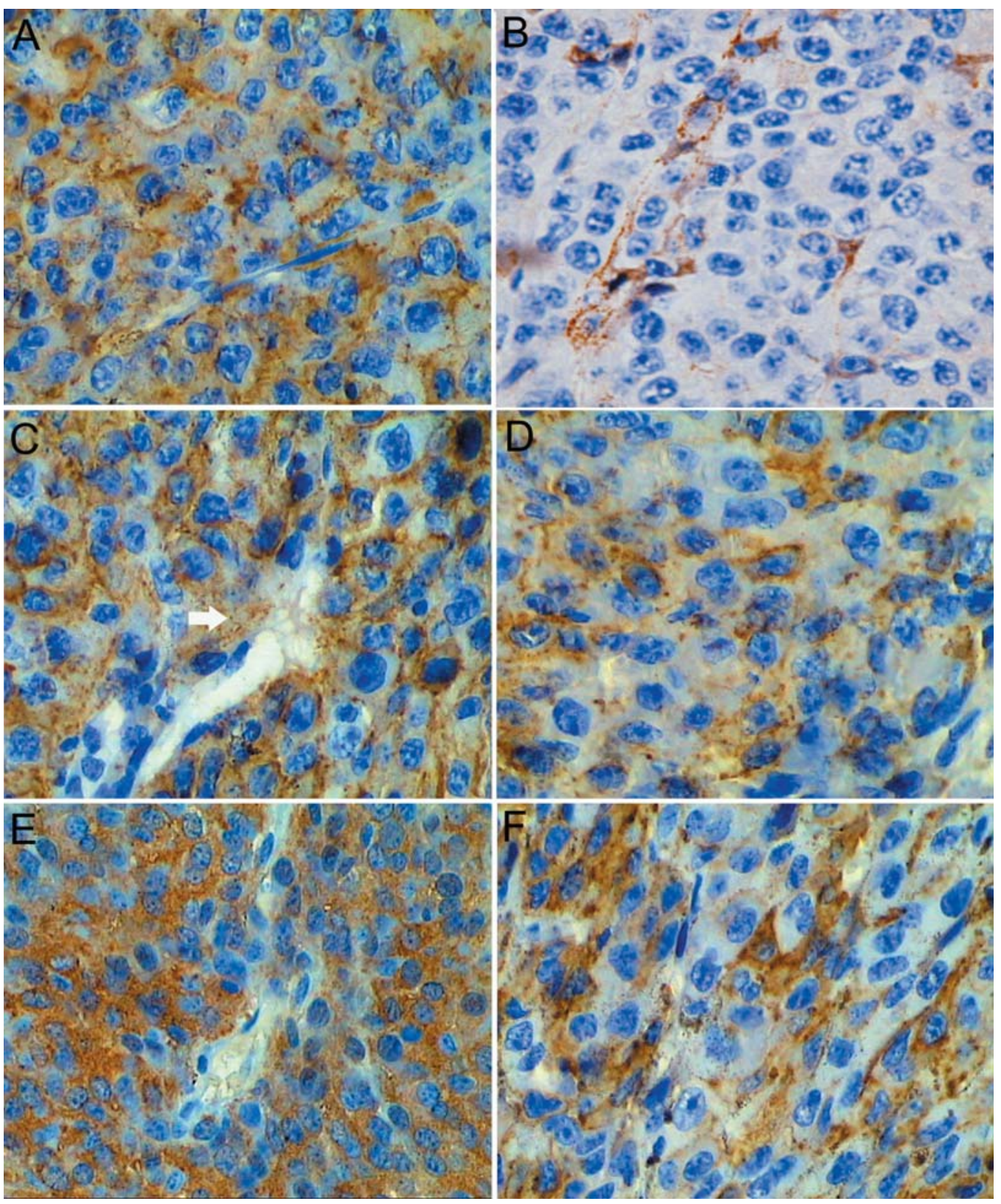

Figure 3. (A) Strong expression of EphA2 in the cytoplasm and membrane of melanoma cells from tumors in the subretinal group (IHC, $\mathrm{x} 400)$. (B) Compared with the subretinal tumors, there was weak expression of EphA2 in the groin group (IHC, x400). (C) Compared with the groin tumors, MMP-2 was strongly positive in melanoma in the subretinal group, especially around the vessel (white arrow) (IHC, x400). (D) Melanoma cells in the groin tumors expressed MMP-2 weakly and infrequently (IHC, x400). (E and F) MMP-9-positive melanoma cells in the two groups. The percentage of positive cells and staining intensity were stronger in the subretinal group (E) than in the groin group (F) (IHC, x400). 


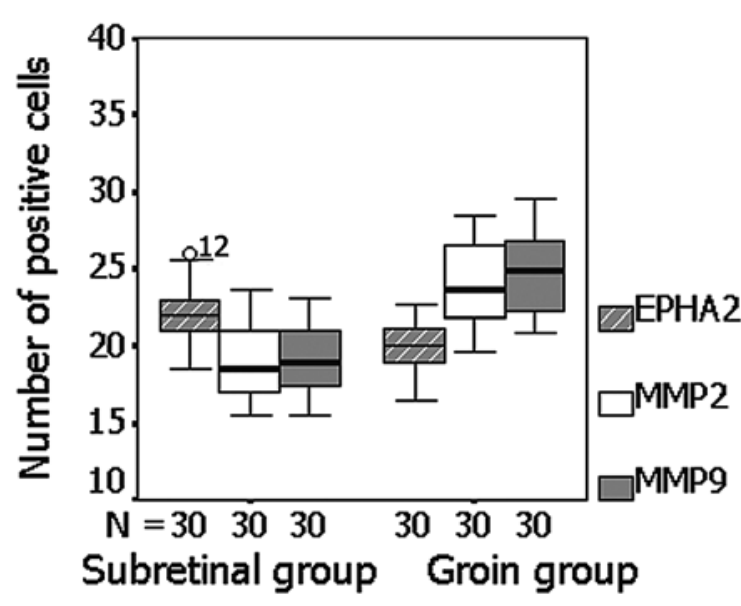

Figure 4. The mRNA levels of EphA2, MMP-2 and MMP-9 were higher in the subretinal group than those in the groin group. The CT value of EphA2, MMP-2 and MMP-9 in the subretinal group was lower than that in the groin group $(\mathrm{P}=0.002,0.001$, and 0.001 , respectively). The horizontal line inside the box represents the median. The outliers are cases with values between 1.5 and 3 box-lengths from the 75 th percentile or the 25 th percentile. The extreme values are cases with values $>3$ box-lengths from the 75 th or the 25 th percentile.

Expression of EphA2, MMP-2 and MMP-9 in the different microenvironments. Immunohistochemical staining showed expression of EphA2 in the cytoplasm of melanoma cells. Melanoma growing in the subretinal group expressed more EphA2 than that in the groin group (Fig. 3A and B; and data not shown). There was strong staining for MMP-2 and -9 in the cytoplasm of tumor cells. Compared with melanoma in the groin area, both MMP-2 and -9 were overexpressed in melanoma in the subretinal group (Fig. 3C-F; and data not shown).

The mRNA level of EphA2, MMP-2 and MMP-9 in the different microenvironments. Real-time PCR results demonstrated that expression of MMP-2 and -9 mRNA in the groin group was decreased compared with the subretinal group. The CT value of EphA2, MMP-2 and MMP-9 in the subretinal group was lower than that in the groin group. There was statistical significance for EphA2, MMP-2 and MMP-9 between the two groups (Fig. 4, $\mathrm{P}=0.002,0.001$ and 0.001 , respectively).

\section{Discussion}

Melanoma is a type of malignant and poorly differentiated tumor which is prone to metastasize, and the prognosis of patients is very poor (11). Furthermore, these patients succumb to the disease quickly after diagnosis because of relapse and metastasis, and the exact mechanism is still unknown (12). Tumors require a blood supply for survival, growth and metastasis. There are three blood supply patterns for melanoma, namely VM, mosaic vessels and endotheliumdependent vessels (13-15). The existence of VM has been shown to be related to metastasis and poor prognosis. Therefore, two groups of mice received injections of melanoma cell suspension in the subretinal space and the groin area, respectively, to investigate the mechanism.
Tumor growth, invasiveness and metastasis are regulated by many associated factors, and tumor cells display distinguished growth patterns and invasive ability in different microenvironments $(16,17)$. The environmental factors impacting tumor cell behavior include interstitial fluid pressure in the tumor tissue, $\mathrm{pH}$, oxygen pressure, focal concentration of cytokines, ECM and microvessel density (18-20). We found 6 micrometastases of the lungs in the subretinal group, but no metastases were found in the groin group. The possible reasons can be outlined as follows. The groin area has more space, and its pressure in a mouse is usually low. There is a distensible interspace for tumor growth in the groin area, so the mechanical stress produced by the growth in tumor size increases slowly. In contrast, the structure of the subretinal space is a small cavity. As the tumor proliferates, the intraocular pressure (IOP) increases greatly. Secondary glaucoma occurs with elevated intraocular pressure. So, tumor cells in a high-pressure microenvironment must secrete proteinases to enable continual growth, invasiveness and metastasis. Hence, high interstitial fluid pressure has more influence on tumor invasiveness and microcirculation patterns than other factors (21). Another potential reason is that the choroid is a frequent metastatic site for blood-borne tumors because of its rich blood supply. Vice versa, intraocular tumors may extend into adjacent tissues or may metastasize to distant site organs.

There was a great difference in tumor microcirculation patterns between the two locations. We found that melanoma in the subretinal space extended into the orbit, while tumors in the groin area diffused with no distinct shape. The subretinal tumors had more VM channels than those in the groin group. These findings demonstrated that melanoma in the subretinal space was perfused mainly by VM. When the microcirculation networks formed by endothelium-dependent vessels were not adequate for supplying blood, tumor cells formed VM channels to enhance perfusion. A possible explanation is that high interstitial fluid pressure in the tumor tissue blocked the sprouting of endothelial cells into the tumor from host tissue. VM channels and endotheliumdependent vessels form networks to supply oxygen and nutrition to growing tumor cells, but they play different roles in tumor growth and development in different microenvironments. That is, as the number of VM channels increases, the melanoma invasiveness and metastasis increases (22). This feature suggests that VM channels can satisfy the needs of melanoma growth. In our study, melanoma tumor development in the subretinal group occurred more slowly than that in the control group. This finding may be associated with the effects of hypoxia and ischemia occurring in the melanoma microenvironment $(23,24)$. In this type of microenvironment, tumor cells can secrete certain proteins or upregulate expression of specific proteins in order to adapt to the poor conditions $(25,26)$.

The potential mechanism involves increased interstitial fluid pressure which leads to ischemia and hypoxia in the tumor. Expression of invasion-associated proteins in tumor cells is then up-regulated to enhance blood perfusion $(27,28)$. This mechanism is an adaptation of tumor cells to the poor intraocular microenvironment. Only tumors cells with the capacity to secrete MMPs are able to survive in an environment with high interstitial fluid pressure. Our results indicate 
that, compared with melanoma growing in the groin area, melanoma in the subretinal space had less necrosis, and expression of MMP-2 and -9 was significantly increased. MMP-2 and -9 degrade ECM components and facilitate tumor angiogenesis, invasion and metastasis (29). We showed that tumor cells with positive MMP-2 and -9 expression were mainly distributed in the boundary between melanoma and normal tissue, especially in the tumor cells invading into the orbital cavity and metastasizing into the lung. Elevated IOP may lead to hypoxia and anoxia. Hypoxia may induce melanoma cells to express and also to activate MMP-2 and -9 , proteinases associated with tumor invasiveness $(9,30)$. To receive adequate oxygen, melanoma cells invade adjacent tissue and undergo distal metastasis. This hypothesis was supported by the growth pattern of melanoma in our study.

EphA2 is a member of the Eph family of protein receptor tyrosine kinases (31). EphA2 plays important and diverse roles in controlling cell adhesion, migration and invasion. It was previously reported that EphA2 also plays a role in tubular formation by aggressive melanoma cells. Transient knockout of EphA2 expression in aggressive uveal melanoma tumor cells resulted in the inhibition of tubular network formation by these cells (32). Our findings indicated that areas containing patterned tubular networks also showed high levels of EphA2, MMP-2 and MMP-9. It was inferred that they may play an important role in the formation of VM channels. The role of EphA2 in the process of tubular network formation was confirmed, and EphA2 was expressed in aggressive melanoma cells. The treated cells were then assessed for their ability to develop tubular structures when cultured on a threedimensional matrix (33). These results, coupled with those of Hess and his co-researchers (34), suggest that EphA2 could be the candidate kinase involved in this process. The MMP-2 protein is considered to play a significant role in VM formation in melanoma in vitro. EphA2 and VE-cadherin could activate MMP-2 through the PI3K pathway, and the activated MMP-2 could cleave the laminin5 $\gamma 2$ chain into 2 segments (laminin $5 \gamma 2 \mathrm{x}$ and laminin $5 \gamma 2$ '), which affects VM formation (34-37). We found expression and activity of MMP-2 and -9 to be correlated with VM formation, and they were more abundant in the subretinal group. We believe that the melanoma cells in the subretinal group secreted and activated MMP-2 and -9, which degraded and remodeled the ECM and then assisted the formation of VM. In this type of microenvironment, tumor cells can secrete certain proteins or up-regulate expression of specific proteins such as EphA2, laminin5 22 and MMPs in order to adapt to hypoxic conditions. Our results demonstrated that different microenvironments affect melanoma cell microcirculation patterns, invasiveness and metastatic behavior. Melanoma cells in an intraocular microenvironment become more aggressive. EphA2, MMP-9 and MMP-2 may play an important role in the formation of VM channels.

\section{Acknowledgements}

This work was supported, in part, by a grant from the National Nature Science Foundation of China. We are grateful to Lucy Zhuo Chen for assistance with the English language amendments.

\section{References}

1. Maniotis AJ, Folberg R, Hess A, Seftor A, Gardner LM, Trent JM, Meltzer PS and Hendrix MJ: Vascular channel formation by human melanoma cells in vivo and in vitro: vasculogenic mimicry. Am J Pathol 155: 739-752, 1999.

2. Bissell MJ: Tumor plasticity allows vasculogenic mimicry, a novel form of angiogenic switch: a rose by any other name? Am J Pathol 155: 675-679, 1999.

3. Sood AK, Seftor EA, Fletcher MS, Gardner LM, Heidger PM, Buller RE, Seftor RE and Hendrix MJ: Molecular determinants of ovarian cancer plasticity. Am J Pathol 158: 1279-1288, 2001.

4. Folberg R, Hendrix MJ and Maniotis AJ: Vasculogenic mimicry and tumor angiogenesis. Am J Pathol 156: 361-381, 2000

5. Seftor EA, Meltzer PS, Kirschmann DA, Maniotis AJ, Trent JM, Folberg R and Hendrix MJ: Molecular determinants of human melanoma invasion and metastasis. Clin Exp Metastasis 19: 233-246, 2002.

6. Rofstad EK, Mathiesen B and Galappathi K: Increased metastatic dissemination in human melanoma xenografts after subcurative radiation treatment: radiation-induced increase in fraction of hypoxic cells and hypoxia-induced up-regulation of urokinase-type plasminogen activator receptor. Cancer Res 64: $13-18,2004$

7. Giatromanolaki A, Koukourakis MI, Sowter HM, Sivridis E, Gibson S, Gatter KC and Harris AL: BNIP3 expression is linked with hypoxia-regulated protein expression and with poor prognosis in non-small cell lung cancer. Clin Cancer Res 10: 5566-5571, 2004.

8. Folgueras AR, Pendas AM, Sanchez LM and Lopez-Otin C: Matrix metalloproteinases in cancer: from new functions to improved inhibition strategies. Int J Dev Biol 48: 411-424, 2004.

9. Hess AR, Seftor EA, Seftor RE and Hendrix MJ: Phosphoinositide 3-kinase regulates membrane type 1-matrix metalloproteinase (MMP) and MMP-2 activity during melanoma cell vasculogenic mimicry. Cancer Res 63: 4757-4762, 2003.

10. Seftor EA, Meltzer PS, Kirschmann DA, Margaryan NV, Seftor RE and Hendrix MJ: The epigenetic reprogramming of poorly aggressive melanoma cells by a metastatic microenvironment. J Cell Mol Med 10: 174-196, 2006.

11. Scala S, Ottaiano A, Ascierto PA, Cavalli M, Simeone E, Giuliano P, Napolitano M, Franco R, Botti G and Castello G: Expression of CXCR4 predicts poor prognosis in patients with malignant melanoma. Clin Cancer Res 11: 1835-1841, 2005.

12. Laurenzi L, Natoli S, Di Filippo F, Calamaro A, Centulio F, Anza M, Cavaliere F, Marcelli ME, Garinei R and Arcuri E: Systemic and haemodynamic toxicity after isolated limb perfusion (ILP) with TNF-alpha. J Exp Clin Cancer Res 23: 225-231, 2004

13. Maniotis AJ: Control of melanoma morphogenesis, endothelial survival, and perfusion by extracellular matrix. Lab Invest 82 : 1031-1043, 2002.

14. Folberg R and Maniotis AJ: Vasculogenic mimicry. APMIS 112: 508-525, 2004.

15. Lee YJ, Nagai N, Siar CH, Nakano K, Nagatsuka H, Tsujigiwa $H$, Roan CH and Gunduz M: Angioarchitecture of primary oral malignant melanomas. J Histochem Cytochem 50: 1555-1562, 2002.

16. Dai J, Keller J, Zhang J, Lu Y, Yao Z and Keller ET: Bone morphogenetic protein- 6 promotes osteoblastic prostate cancer bone metastases through a dual mechanism. Cancer Res 65: 8274-8285, 2005.

17. Miyoshi A, Kitajima Y, Ide T, Ohtaka K, Nagasawa H, Uto Y, Hori $\mathrm{H}$ and Miyazaki K: Hypoxia accelerates cancer invasion of hepatoma cells by upregulating MMP expression in an HIF-1 $\alpha-$ independent manner. Int J Oncol 29: 1533-1539, 2006.

18. Nguyen QD, Wever O, Bruyneel E, Hendrix A, Xie WZ, Lombet A, Leibl M, Mareel M, Gieseler F, Bracke M and Gespach C: Commutators of PAR-1 signaling in cancer cell invasion reveal an essential role of the Rho-Rho kinase axis and tumor microenvironment. Oncogene 24: 8240-8251, 2005.

19. Dong D, Baumeister P, Swenson S, Costa F, Markland F, Stiles C, Patterson JB, Bates SE and Lee AS: Vascular targeting and antiangiogenesis agents induce drug resistance effector GRP78 within the tumor microenvironment. Cancer Res 65: 5785-5791, 2005.

20. Yagmurdur MC, Basaran O, Ozdemir H, Gur G, Tran M, Karakayali $\mathrm{H}$ and Haberal M: The impact of transient elevation of intra-abdominal pressure on liver regeneration in the rat. J Invest Surg 17: 315-322, 2004. 
21. Pietras K, Ostman A, Sjoquist M, Buchdunger E, Reed RK, Heldin $\mathrm{CH}$ and Rubin K: Inhibition of platelet-derived growth factor receptors reduces interstitial hypertension and increases transcapillary transport in tumors. Cancer Res 61: 2929-2934, 2001.

22. Sun BC, Zhang SW, Zhao XL and Hao XS: Study on vasculogenic mimicry in malignant melanoma. Zhonghua Bing Li Xue Za Zhi 32: 539-543, 2003.

23. Gross J, Fuchs J, Machulik A, Jahnke V, Kietzmann T and Bockmuhl U: Apoptosis, necrosis and hypoxia inducible factor-1 in human head and neck squamous cell carcinoma cultures. Int J Oncol 27: 807-814, 2005.

24. Weinmann M, Jendrossek V, Guner D, Goecke B and Belka C: Cyclic exposure to hypoxia and reoxygenation selects for tumor cells with defects in mitochondrial apoptotic pathways. FASEB J 18: 1906-1908, 2004.

25. Seta KA and Millhorn DE: Functional genomics approach to hypoxia signaling. J Appl Physiol 96: 765-773, 2004.

26. Seftor EA, Meltzer PS, Schatteman GC, Gruman LM, Hess AR, Kirschmann DA, Seftor RE and Hendrix MJ: Expression of multiple molecular phenotypes by aggressive melanoma tumor cells: role in vasculogenic mimicry. Crit Rev Oncol Hematol 44: 17-27, 2002.

27. Sun B, Zhang D, Zhang S, Zhang W, Guo H and Zhao X: Hypoxia influences vasculogenic mimicry channel formation and tumor invasion-related protein expression in melanoma. Cancer Lett 249: 188-197, 2007.

28. Sun LC, Luo J, Mackey LV, Fuselier JA and Coy DH: A conjugate of camptothecin and a somatostatin analog against prostate cancer cell invasion via a possible signaling pathway involving PI3K/Akt, alphaVbeta3/alphaVbeta5 and MMP-2/-9. Cancer Lett 246: 157-166, 2007.

29. Williams TM, Medina F, Badano I, Hazan RB, Hutchinson J, Muller WJ, Chopra NG, Scherer PE, Pestell RG and Lisanti MP: Caveolin-1 gene disruption promotes mammary tumori-genesis and dramatically enhances lung metastasis in vivo. Role of Cav-1 in cell invasiveness and matrix metalloproteinase (MMP-2/9) secretion. J Biol Chem 279: 51630-51646, 2004.
30. Brat DJ, Castellano-Sanchez AA, Hunter SB, Pecot M, Cohen C, Hammond EH, Devi SN, Kaur B and Van Meir EG: Pseudopalisades in glioblastoma are hypoxic, express extracellular matrix proteases, and are formed by an actively migrating cell population. Cancer Res 64: 920-927, 2004.

31. Zelinski DP, Zantek ND, Stewart J, Irizarry A and Kinch MS: EphA2 overexpression causes tumorigenesis of mammary epithelial cells. Cancer Res 61: 2301-2306, 2001.

32. Brantley DM, Cheng N, Thompson EJ, et al: Soluble Eph A receptors inhibit tumor angiogenesis and progression in vivo. Oncogene 21: 7011-7026, 2002.

33. Ogawa K, Pasqualini R, Lindberg RA, Kain R, Freeman AL and Pasquale EB: The ephrin-A1 ligand and its receptor EphA2, are expressed during tumor neovascularization. Oncogene 19: 6043-6052, 2000.

34. Hess AR, Seftor EA and Gardner LM: Molecular regulation of tumor cell vasculogenic mimicry by tyrosine phosphorylation: role of epithelial cell kinase (Eck/EphA2). Cancer Res 61: 3250-3255, 2001

35. Seftor RE, Seftor EA and Koshikawa N: Cooperative interactions of laminin 5 gamma2 chain, matrix metalloproteinase-2, and membrane type-1-matrix/metalloproteinase are required for mimicry of embryonic vasculogenesis by aggressive melanoma. Cancer Res 61: 6322-6327, 2001.

36. Hendrix MJ, Seftor EA, Hess AR and Seftor RE: Vasculogenic mimicry and tumor-cell plasticity: lessons from melanoma. Nat Rev Cancer 3: 411-421, 2003.

37. Hess AR, Seftor EA, Gruman LM, Kinch MS, Seftor RE and Hendrix MJ: VE-cadherin regulates EphA2 in aggressive melanoma cells through a novel signaling pathway. Implications for vasculogenic mimicry. Cancer Biol Ther 5: 228-233, 2006. 